\title{
PEMANFAATAN AMONIASI UREA KULIT DAGING BUAH KOPI PADA PAKAN DOMBA TERHADAP KARKAS DOMBA JANTAN LEPAS SAPIH
}

\author{
(Utilization of Ammoniated Coffee Pulp In Sheep Ration On Carcas Of Weaned Sheep)
}

\author{
Amelia Novaiza, Armyn Hakim Daulay, dan Iskandar Sembiring \\ Program Studi Peternakan Fakultas Pertanian Universitas Sumatera Utara
}

\begin{abstract}
The purpose of this research to study the utilization of ammoniated coffee pulp in sheep Concentrate on Carcas of weaned sheep. The research was done in Laboratory of Animal Biology Department of Animal science, Faculty of Agriculture, University of Sumatera Utara, for 3 months from 20 August 2010 to 11 November 2010. The research methodology used 20 male sheeps with average initial body weight $13.80 \pm 1,27$ kgand using completely randomized design (CRD) methods which consist of 4 treatments and 5 replications. The level of the ammoniated coffee pulp is P0 (concentrate supplemented with 30\% coffee pulp without ammoniated), P1 (concentrate supplemented with 15\% ammoniated coffee pulp), P2 (concentrate supplemented with $30 \%$ ammoniated coffee pulp), P3 (concentrate supplemented with 45\% ammoniated coffee pulp). The result this research indicated that empty body weight $(\mathrm{kg} / \mathrm{head})$ for treatments P0,P1,P2,P3 were 12.74, 13:16, 13.00, 12.99, respectively. Carcass percentage for treatments P0,P1,P2,P3 were 49.19, 54.26, 53.79, 47.92, respectively, while with the same order on subcutaneous fat percentage were $1.91,2.03,1.95,1.51$, on heart fat percentage were $4: 55,4.72,4.25,4.38$, on kidney fat percentage were $3.79,4.05,3.96,3.68$, and pelvic fat percentage were $3.47,3.70,3.49$, 3.27. For all of the variables indicated that the treatment had no significant effect $(\mathrm{P}>0.05)$. It is concluded that coffee pulp can be applied as part of feed concentrate on sheep.
\end{abstract}

Keyword: sheep, coffee pulp, ammoniated, empty body weight, carcass,

\begin{abstract}
ABSTRAK
Penelitian ini bertujuan untuk melihat potensi pemanfaatan dari kulit daging buah kopi yang diamoniasi terhadap persentase karkas domba jantan lepas sapih. Penelitian dilaksanakan di Laboratorium Biologi Ternak Program Studi Peternakan Fakultas Pertanian Universitas Sumatera Utara selama 3 (tiga) bulan dimulai bulan 20 Agustus 2010 sampai 11 November 2010. Metode penelitian ini menggunakan 20 ekor domba jantan dengan rataan bobot badan awal $13.80 \pm 1.27$ kgdan rancangan acak lengkap (RAL) yang terdiri dari 4 perlakuan dan 5 ulangan. Perlakuan konsentrat yang digunakan adalah kulit daging buah kopi yang tidak diamoniasi dan yang diamoniasi dengan level pemberian sebagai berikut, P0 (Pemberian konsentrat kulit daging buah kopi yang tidak diamoniasi sebesar 30\%), P1 (Pemberian konsentrat menggunakan kulit daging buah kopi diamoniasi dengan level 15\%), P2 (Pemberian konsentrat menggunakan kulit daging buah kopi diamoniasi dengan level 30\%), P3 (Pemberian konsentrat menggunakan kulit daging buah kopi diamoniasi dengan level 45\%). Hasil penelitian menunjukkan bahwa pada bobot tubuh kosong pada perlakuan $\mathrm{P} 0=12.74, \mathrm{P} 1=13.16, \mathrm{P} 2=13.00, \mathrm{P} 3=12.99$, persentase karkas pada perlakuan $\mathrm{P} 0=49.19, \mathrm{P} 1=54.26, \mathrm{P} 2=53.79, \mathrm{P} 3=47.92$, persentase lemak subkutan pada perlakuan $\mathrm{P} 0=$ $1.91, \mathrm{P} 1=2.03, \mathrm{P} 2=1.95, \mathrm{P} 3=1.51$, persentase lemak jantung pada perlakuan $\mathrm{P} 0=4.55, \mathrm{P} 1=4.72, \mathrm{P} 2=4.25, \mathrm{P} 3$ $=4.38$, persentase lemak ginjal pada perlakuan $\mathrm{P} 0=3.79, \mathrm{P} 1=4.05, \mathrm{P} 2=3.96, \mathrm{P} 3=3.68$, persentase lemak pelvis pada perlakuan $\mathrm{P} 0=3.47, \mathrm{P} 1=3.70, \mathrm{P} 2=3.49, \mathrm{P} 3=3.27$. Hasil analisis ragam menunjukkan bahwa untuk semua peubah perlakuan tidak memberikan pengaruh yang nyata $(\mathrm{P}>0,05)$. Dapat disimpulkan bahwa kulit daging buah kopi dapat digunakan sebagai komponen konsentrat untuk domba.
\end{abstract}

Kata kunci : Domba, Kulit daging buah kopi, Amoniasi, Bobot Tubuh Kosong, karkas. 


\section{PENDAHULUAN}

Harga domba pada tiap tahunnya senantiasa mengalami kenaikan namun hasil penelusuran lapangan yang dilakukan dimana pengaruh kenaikan harga terhadap indeks penghasilan peternak rakyat tidak terlampau signifikan. Perkembangan peternakan domba sampai saat ini relatif jalan di tempat, perkembangan produksi dan produktivitasnya hampir tidak mengalami kemajuan berarti, hal ini diduga akibat pola pemeliharaannya yang masih bersifat tradisional dengan skala pemilikan yang kecil (small holders). Populasi domba di Indonesia saat ini mencapai 7.549 316 ekor, sedangkan populasi domba di Jawa Barat mencapai 4.221.806 ekor (55,92 \% populasi nasional) dan pemotongan domba yang tercatat di Jawa Barat pada Tahun 2006 mencapai 3.343.365 ekor, (Statistik Peternakan, 2006). Artinya permintaan daging domba di Jawa Barat sangat tinggi dan nyaris menguras populasi yang ada.

Karkas adalah jika hewan telah dipotong, semua isi perut kecuali buah pinggang dan isi dada dan isi perut telah dikeluarkan, kepala, kulit, ekor dan kaki bagian bawah telah dipisahkan, maka bagian yang telah bersih biasanya digantung (Sumasprastowo, 1993). Secara umum, daging terdiri dari air dan bagian bahan padat. Bahan padat pada daging terdiri dari bahan-bahan yang mengandung nitrogen, mineral, garam dan abu. Lebih kurang $20 \%$ dari seluruh bahan padat daging merupakan protein. Komposisi daging relatif mirip satu sama lain, terutama kandungan proteinnya yang berkisar 15-20 persen dari berat bahan. Kaitan karkas dengan pakan ialah dimana pakan yang baik juga akan mempengaruhi karkas yang baik, yang perlu diperhatikan ialah hijauan yang diberikan kepada domba tersebut. Kelompok hijauan yang berkualitas tinggi terdiri dari potein kasar diatas 10\% dari bahan kering, energi diatas 50\% TDN dari bahan kering, kalsium diatas $1 \%$ dari bahan kering. Hijauan yang termasuk kelompok ini yaitu legium (kaliandra, glirycidia), alfalfa dan umbi-umbian.

Permasalahan pakan yang paling utama yang tidak bisa dijangkau oleh petani peternak kecil contohnya pakan komersil dan bahan-bahan yang digunakan dalam pakan yang disusun sendiri oleh petani peternak. Salah satu alternatif utama yaitu dengan memanfaatkan hasil dari limbah kulit daging buah kopi dimana hasil dari limbah kulit daging buah kopi ini tidak dimanfaatkan oleh orang banyak. Kulit daging buah kopi di daerah ini dibuang begitu saja dan hanya digunakan sebagai pupuk organik saja. Kulit daging buah kopi ini masih mengandung nutrisi yang sangat potensial untuk digunakan sebagai pakan ternak ruminansia seperti domba. Menurut Loka Penelitian Domba Galang Sumatera Utara, limbah kulit daging buah kopi 
sebanyak 752,6-846,7 ton/hari (Dolok Sanggul). Kulit daging buah kopi mengandung serat kasar $(21,74 \%)$ dan protein $(11,18 \%)$, maka perlu ditingkatkan kualitasnya agar pemanfaatannya dapat lebih optimal untuk ruminansia. Pengolahan cara kimia dengan amoniak $\left(\mathrm{NH}_{3}\right)$ disebut sebagai amoniasi. Keuntungan pengolahan ini, selain meningkatkan daya cerna juga sekaligus meningkatkan kadar protein, dapat menghilangkan aflatoksin dan pelaksanaannya sangat mudah. Kelemahannya pengolahan ini utamanya untuk pakan ruminansia. Zat-zat yang terkandung didalam kulit daging buah kopi adalah : Protein kasar (11,18\%), Bahan kering (91,77\%), Lemak (2,5\%), Serat kasar (21,74\%), Tanin (2,47\%), Kafein (1,36\%), Lignin (52,59\%), dan TDN $(57,20 \%)$.

Berdasarkan publikasi oleh Fakultas Peternakan Undip (2005) salah satu kendala pemanfaatan daging kulit buah kopi sebagai pakan ternak adalah kandungan serat kasarnya yang tinggi (21,74\%), sehingga tingkat kecernaannya sangat rendah. Dengan proses amoniasi, tingkat kecernaan kulit kopi bisa ditingkatkan. Bukan hanya itu, amoniasi kulit kopi juga dapat meningkatkan kadar protein serta menghilangkan aflatoksin.

\section{BAHAN DAN METODE}

\section{Lokasi dan Waktu Penelitian}

Penelitian ini dilaksanakan di Laboratorium Biologi Ternak, Program Studi Peternakan, Fakultas Pertanian, Universitas Sumatera Utara, Medan. Penelitian berlangsung selama 3 bulan dimulai bulan 20 Agustus 2010 sampai 11 November 2010.

\section{Bahan}

Domba yang digunakan adalah domba lokal jantan lepas sapih sebanyak 20 ekor dengan bahan pakan yang akan diberikan terdiri atas : Hijauan (rumput lapangan), konsentrat (kulit daging buah kopi tanpa diamoniasi, kulit daging buah kopi yang diamoniasi, bungkil inti sawit, dedak padi, onggok, pelepah daun sawit, lumpur sawit, ultra mineral, garam, urea, molasses. Obat-obatan seperti obat cacing (Kalbazen), anti bloat untuk obat kembung, terramycin (salep mata) dan vitamin B-Kompleks diberikan untuk menjaga daya tahan tubuh domba, air minum, desinfektan (Rodalon). 


\begin{abstract}
Alat
Kandang terdiri atas kandang individu 20 unit dengan ukuran 1 x $1 \mathrm{~m}^{2}$ beserta perlengkapannya, ember sebanyak 20 buah tempat pakan dan 20 buah tempat minum, timbangan untuk menimbang bobot hidup berkapasitas $150 \mathrm{~kg}$ dengan kepekaan $50 \mathrm{~g}$, timbangan berkapasitas $2 \mathrm{~kg}$ dengan kepekaan $10 \mathrm{~g}$ untuk menimbang pakan, terpal plastik untuk menjemur bahan pakan, alat penerangan, goni plastik, alat tulis, chopper, mixer, sapu, sekop untuk membersihkan kandang, ember, air, pisau untuk menyembelih domba, tali rafia dan kantong plastik untuk kemasan karkas.
\end{abstract}

\title{
Metode Penelitian
}

Rancangan percobaan yang digunakan adalah Rancangan acak lengkap (RAL) non faktorial dengan 4 perlakuan dan 5 ulangan, dengan perlakuan :

$\mathrm{P} 0=$ Pemberian konsentrat yang menggunakan kulit kopi tanpa diamoniasi dengan level sebesar $30 \%+$ rumput lapangan.

$\mathrm{P} 1=$ Pemberian konsentrat yang menggunakan kulit kopi diamoniasi dengan level sebesar $15 \%$ + rumput lapangan.

P2 = Pemberian konsentrat yang menggunakan kulit kopi diamoniasi dengan level sebesar $30 \%$ + rumput lapangan.

P3 = Pemberian konsentrat yang menggunakan kulit kopi diamoniasi dengan level sebesar $45 \%$ + rumput lapangan.

\section{Peubah Penelitian}

1. Bobot Tubuh Kosong, yaitu bobot potong dikurang dengan isi saluran pencernaan.

2. Persentase Karkas, yaitu bobot karkas segar dibagi dengan bobot tubuh kosong dikali 100\%.

3. Persentase Lemak

- lemak subkutan yaitu lemak yang diperoleh dari lemak pada bagian bawah kulit dibagi dengan bobot karkas dikali 100\%

- lemak jantung yaitu lemak yang diperoleh dari lemak yang menyelubungi jantung dibagi dengan bobot karkas dikali 100\%

- lemak ginjal yaitu lemak yang diperoleh dari lemak yang menyelubungi ginjal dibagi dengan bobot karkas dikali $100 \%$

- lemak pelvis yaitu lemak yang diperoleh dari lemak pada begian sekitar pelvis dibagi bobot karkas dikali $100 \%$. 


\section{HASIL DAN PEMBAHASAN}

\section{Bobot tubuh kosong}

Bobot tubuh kosong penelitian diperoleh yaitu bobot tubuh kosong dikurang isi saluran pencernaan. Dapat dilihat bahwa rataan bobot tubuh kosong yang tertinggi terdapat pada perlakuan P1 yaitu sebesar 13.16 (kg/ekor) dan rataan bobot tubuh kosong terendah terdapat pada perlakuan P1 yaitu sebesar 12.74 (kg/ekor). Hasil penelitian disajikan pada Tabel 1.

Tabel 1. Pengaruh penggunaan kulit kopi terhadap karkas domba

\begin{tabular}{|c|c|c|c|c|}
\hline \multirow{2}{*}{ Peubah } & \multicolumn{4}{|c|}{ Perlakuan } \\
\hline & $\mathrm{PO}$ & $\mathrm{P} 1$ & $\mathrm{P} 2$ & P3 \\
\hline Bobot tubuh kosong $(\mathrm{kg})^{\text {tn }}$ & 12.74 & 13.16 & 13.00 & 12.99 \\
\hline Persentase karkas $(\%)^{\operatorname{tn}}$ & 49.19 & 54.26 & 53.79 & 47.92 \\
\hline Persentase lemak subkutan $(\%)^{\text {tn }}$ & 1.91 & 2.03 & 1.95 & 1.51 \\
\hline Persentase lemak jantung $(\%)^{\text {th }}$ & 4.55 & 4.72 & 4.25 & 4.38 \\
\hline Persentase lemak ginjal $(\%)^{\text {tn }}$ & 3.79 & 4.05 & 3.96 & 3.68 \\
\hline Persentase lemak pelvis $(\%)^{\text {th }}$ & 3.47 & 3.70 & 3.49 & 3.27 \\
\hline
\end{tabular}

Hasil analisis ragam menunjukkan bahwa pemberian konsentrat kulit kopi yang diamoniasi memberikan pengaruh yang tidak nyata terhadap bobot tubuh kosong. Hal ini disebabkan ransum yang diberikan pada tiap perlakuan memberikan pengaruh terhadap isi saluran pencernaan pada domba dimana level pemberian konsentrat sudah optimum sehingga menyebabkan adanya perbedaan yang nyata antara ransum kontrol dengan ransum yang diberi amoniasi kulit kopi. Hal ini sesuai dengan pendapat Siregar (1994), yang menyatakan ternak ruminansia mampu mencerna hijauan termasuk rumput-rumputan yang umumnya mengandung selulosa tinggi. Hal ini disebabkan oleh adanya mikroorganisme didalam rumen, makin tinggi populasinya maka akan semakin tinggi kemampuannya untuk mencerna selulosa yang digunakan untuk pertumbuhan dan perkembangan populasi. Mikroorganisme didalam rumen membutuhkan protein, energi, mineral dan sejumlah vitamin (Siregar, 1994). Dalam pemberian pakan, pertumbuhan bobot tubuh juga dipengaruhi oleh konsumsi pakan dan komposisi pakan. Kenaikan atau penurunan konsumsi pakan dapat berhubungan dengan kualitas pakan dan sebagainya. 


\section{Karkas}

\section{Persentase karkas}

Persentase karkas didapat dari perbandingan bobot karkas segar dengan bobot tubuh kosong dikali $100 \%$. Dapat dilihat bahwa rataan persentase yang tertinggi terdapat pada perlakuan P1 sebesar 54.26\% dan bobot karkas terendah terdapat pada perlakuan P3 sebesar 47.92\%. Rataan persentase karkas dipengaruhi oleh rataan bobot karkas, rataan bobot karkas tertinggi terdapat pada perlakuan P1 sebesar 7.40 kgdengan rataan persentase karkas tertinggi pada perlakuan P1 juga yaitu 54.26\%.

Hal ini sesuai dengan pendapat Sumasprastowo (1993), yang menyatakan bahwa persentase karkas domba khusus digemukkan 56-58\%, domba yang gemuk 45-55\% dan domba umur 12-16 minggu 48-50\%. Peningkatan persentase karkas juga sejalan dengan pertambahan bobot hidup domba. Hal ini sesuai dengan pendapat Davendra (1997) yang menyatakan bahwa karkas merupakan faktor yang penting untuk menilai produksi ternak pedaging, karena sangat erat hubungannya dengan bobot hidup dimana semakin bertambah bobot hidup maka produksi karkas juga akan meningkat.

Hasil analisis ragam menunjukkan bahwa $\mathrm{F}$ hitung lebih kecil dari $\mathrm{F}$ tabel sehingga disimpulkan bahwa pemberian pakan dengan menggunakan kulit daging buah kopi yang tidak diamoniasi dengan level 30\% dan kulit daging buah kopi yang diamoniasi dengan level $15 \%, 30 \%$ dan $45 \%$ dalam pakan domba lokal jantan memberikan pengaruh yang tidak nyata terhadap persentase bobot karkas.

\section{Persentase lemak subkutan domba}

Diperoleh dari lemak pada bagian bawah kulit karkas dibagi dengan bobot karkas dikali $100 \%$. Dapat dilihat bahwa rataan persentase yang tertinggi terdapat pada perlakuan P1 sebesar 2.03 dan terendah terdapat pada perlakuan P3 sebesar 1.51. Pada perlakuan P1 bobot lemak subkutan yang dihasilkan tinggi karena bobot karkas maupun bobot tubuh kosong tertinggi. Sedangkan perlakuan P3 bobot lemak subkutan yang dihasilkan rendah disebabkan karena bobot karkas maupun bobot tubuh kosong rendah. Hal ini sesuai dengan 
pendapat Mulyadi (1983), yang menyatakan bahwa semakin tinggi bobot karkas, persentase daging dan lemak meningkat pula.

Hasil analisis ragam menunjukkan bahwa $F$ hitung lebih kecil dari $F$ tabel pada taraf 0.05\% yang berarti perlakuan $\mathrm{P} 0, \mathrm{P} 1, \mathrm{P} 2$, dan $\mathrm{P} 3$ pada domba memberikan pengaruh yang yang tidak nyata terhadap bobot lemak subkutan domba. Peneliti berasumsi bahwa bobot lemak dipengaruhi oleh jumlah pakan yang dikonsumsi. Hal ini sesuai dengan pernyataan Berg dan Butterfield (1976) yang menyatakan bahwa jumlah lemak dalam tubuh adalah paling beragam dan sangat tergantung pada jumlah pakan yang dikonsumsi.

\section{Persentase bobot lemak ginjal domba}

Diperoleh dari lemak pada bagian yang menyelubungi ginjal dibagi bobot karkas dikali 100\%. Dapat dilihat bahwa rataan yang tertinggi terdapat pada perlakuan P1 sebesar 4.05, P2 sebesar 3.96, P0 (Pemberian konsentrat yang menggunakan kulit kopi tanpa amoniasi dengan level sebesar 15\%) sebesar 3.79 dan bobot karkas terendah terdapat pada perlakuan P3 (Pemberian konsentrat yang menggunakan kulit kopi diamoniasi dengan level sebesar 45\% ) sebesar 3.68. Hasil analisis ragam menunjukkan bahwa $\mathrm{F}$ hitung lebih kecil dari $\mathrm{F}$ tabel pada taraf $0.05 \%$ yang berarti perlakuan $\mathrm{P} 0, \mathrm{P} 1, \mathrm{P} 2$, dan $\mathrm{P} 3$ pada domba memberikan pengaruh yang yang tidak nyata terhadap bobot lemak ginjal domba.

\section{Persentase bobot lemak jantung domba}

Yaitu yang diperoleh dari lemak yang menyelubungi jantung dibagi dengan bobot karkas dikali 100\%. Dapat dilihat bahwa rataan yang tertinggi terdapat pada perlakuan P1 sebesar 4.72, bobot karkas terendah terdapat pada perlakuan P2 sebesar 4.25. Hasil analisis ragam menunjukkan bahwa $\mathrm{F}$ hitung lebih kecil dari $\mathrm{F}$ tabel pada taraf $0.05 \%$ yang berarti perlakuan P0, P1, P2, dan P3 pada domba memberikan pengaruh yang yang tidak nyata terhadap bobot lemak jantung domba.

\section{Persentase bobot lemak pelvis domba}

Bobot lemak pelvis adalah bobot lemak yang terdapat pada bagian sekitar pelvis dibagi bobot karkas dikali 100\%. Dapat dilihat bahwa rataan yang tertinggi terdapat pada perlakuan P1 sebesar 3.70, bobot karkas terendah terdapat pada perlakuan P3 sebesar 3.27. 
Hasil analisis ragam menunjukkan bahwa $\mathrm{F}$ hitung lebih kecil dari $\mathrm{F}$ tabel pada taraf $0.05 \%$ yang berarti perlakuan P0, P1, P2, dan P3 pada domba memberikan pengaruh yang yang tidak nyata terhadap bobot lemak pelvis domba.

\section{KESIMPULAN}

Kebaradaan kulit daging buah kopi yang diamoniasi pada pakan domba masih memberikan pengaruh positif dimana dengan pemberian kulit daging buah kopi tidak menurunkan bobot dari karkas domba tersebut.

\section{DAFTAR PUSTAKA}

Badan Pusat Statistik., 2003. Hasil Produksi Kopi Di Indonesia. Jakarta.

Davendra. C., 1977. Utilization of Feeding Tuff for Livesstock in South East Asia Malaysia Agricultura Research and Development Institute Serdang Malaysia.

Frandson, R.D., 1992. Anatomi dan Fisiologi Ternak. Gajah Mada University-Press. Yogyakarta.

Hanafiah, K.A., 2003. Rancangan Percobaan. Fakultas Pertanian, Universitas Sriwijaya, Palembang.

Murni, R., Suparjo., Akmal dan Ginting, D.L., 2008. Buku Ajar Teknologi Pemanfaatan Limbah Untuk Pakan. Laboratorium Makanan Ternak Fakultas Peternakan Universitas Jambi.

Murtidjo, B. A., 1992. Memelihara Domba. Kanisius, Yogyakarta.

NRC, 1995. Nutrient Requirement of Domestic no. 2 Nutrien Requirement of Swine National Academy of Washington DC.

Obst, J.M., T. Boyes dan J.B. Moran, 1978. Nilai Nutrisi Rumput Gajah sebagai ransum Dasar Untuk Pertumbuhan Domba di Indonesia, Proc. Seminar Ruminansia. Dit Jen. Pet P4 dan FAPET IPB, Bogor.

Siregar, S.B., 1995. Pengawetan Pakan Ternak. Penebar Swadaya, Jakarta.

Sumasprastowo. C.D.A., 1993. Ternak Domba Pedaging ddan Wol. Bhrata Karya Aksara Jakarta. 